\title{
Transfecção de DNA de BoHV-5 com fosfato de cálcio em diferentes tipos de cultivos celulares
}

Transfection of BoHV-5 DNA with calcium phosphate in different types of cell culture

\author{
Eduardo Bortoluzzi Dornelles ${ }^{1 *}$, Franciscus Antonius Maria Rijsewijk ${ }^{2}$, Paulo Michel Roehe ${ }^{2,3}$ \& Amauri \\ Braga Simonetti ${ }^{1}$
}

\begin{abstract}
RESUMO
As condições para uma transfecção eficaz pelo método de fosfato de cálcio podem variar substancialmente. Neste estudo foi testado o tipo de cultivo celular mais apropriado para transfecção de DNA de herpesvírus bovino tipo 5 (BoHV-5) por esta técnica. Primeiramente foi avaliada a capacidade de multiplicação do BoHV-5 em três diferentes tipos de células. Para isto, a concentração viral foi calculada pelo método de dose infectante para cultivo celular / 50\% (TCID $50 / \mathrm{mL})$. O BoHV-5 foi titulado em células de linhagem de rim de macaco verde Africano (VERO), células de linhagem de rim de suíno (PKsC3), células primárias de testículos de terneiro (TT) e células de linhagem de rim de bovino (MDBK). Em células VERO e PKsC3 a concentração viral máxima obtida foi $10^{3,3} \mathrm{TCID}_{50} / \mathrm{mL}$, enquanto que em células $\mathrm{MDBK}$ o título foi de $10^{6,8} \mathrm{TCID}_{50} / \mathrm{mL}$, similar ao encontrado para as células TT. Para avaliar a eficácia da transfecção nessas células, foi utilizado DNA plasmideal expressando um gene repórter (EGFP). Os resultados mostraram um valor de 4,5\% de células fluorescentes para células TT, de 2,9\% para PKsC3, de 0,5\% para VERO e de 0,05\% para MDBK. Quando células PKsC3 e TT foram transfectadas com 0,5 $\mu \mathrm{g}$ de DNA purificado de BoHV-5, somente as células TT apresentaram resultado positivo, com duas placas virais por poço. Para investigar a influência da concentração de DNA viral, células TT foram transfectadas com 0,5 $\mu \mathrm{g}$ e $1 \mu \mathrm{g}$ de DNA purificado de BoHV-5, produzindo duas e quatro placas, respectivamente. Nas condições experimentais testadas neste estudo os resultados indicam que as células TT poderiam ser boas candidatas para serem utilizadas para a transfecção de DNA de BoHV-5.
\end{abstract}

Descritores: BoHV-5, fosfato de cálcio, transfecção, células de testículo de terneiro.

\section{ABSTRACT}

The conditions for an efficacious transfection by calcium phosphate method can vary substantially. In this study the most appropriate cell type for transfection of bovine herpesvirus type 5 (BoHV-5) DNA using this technique was tested. It was first evaluated the capacity of BoHV-5 multiplication in three different cell types. For this purpose virus concentration was calculated by tissue culture infectious dose $50 \%$ assay $\left(\mathrm{TCID}_{50} \mathrm{~mL}\right)$. BoHV-5 was titrated in kidney cells from African green monkey (VERO), cell clone of pig kidney (PKsC3), primary cell culture of calf testis (TT) and bovine kidney cells (MDBK). In Vero and PK15 cells maximum virus concentration reached $10^{3,3} \mathrm{TCID}_{50} / \mathrm{mL}$, whereas in MDBK cells the titre was $10^{6,8} \mathrm{TCID}_{50} / \mathrm{mL}$, similar to that of TT cells. In order to evaluate the transfection efficacy in these cells, plasmid DNA expressing a reporter gene (EGFP) was used. Results showed $4.5 \%$ fluorescent cells for TT, $2.9 \%$ for PKsC3, $0.5 \%$ for VERO and $0.05 \%$ for MDBK cells. When PKsC3 and TT cells were transfected with $0.5 \mathrm{mg}$ of BoHV-5 purified DNA, only TT cells gave positive result with two plaques per well. To investigate the influence of viral DNA concentration, TT cells were then transfected with $0.5 \mathrm{mg}$ and 1.0 mg of purified BoHV-5 DNA producing two and four plaques, respectively. Under experimental conditions tested in this study the results indicate that TT cells could be good candidates to be used for transfection of BoHV-5 DNA.

Keywords: BoHV-5, calcium phosphate, transfection, calf testicle cells. 


\section{INTRODUÇÃO}

O herpesvírus bovino 5 (BoHV-5) pertence à família Herpesviridae, subfamília Alphaherpesvirinae, gênero Varicellovirus. O BoHV-5 é considerado o mais importante agente da neuroencefalite herpética bovina, que é uma doença que afeta principalmente bovinos jovens [14]. Entretanto, ainda não se sabe qual ou quais genes são responsáveis por essa neuroencefalite. Para investigar essa questão têm sido construídos herpesvírus bovinos recombinantes [4].

Dentre os métodos de transfecção de DNA, a precipitação com fosfato de cálcio é o mais simples e barato [5]. O fundamento desta técnica baseia-se na mistura de DNA com cloreto de cálcio e fosfato, em um tampão salino com $\mathrm{pH}$ exato para a formação de complexos de fosfato de cálcio+DNA. Esses complexos têm a função de ajudar o DNA a atravessar a membrana citoplasmática da célula, para alcançar o núcleo celular e proteger o DNA contra a ação de DNAses $[2,6,7,10]$. Apesar da relativa facilidade de execução, essa técnica requer uma boa padronização para que seja obtida uma alta eficácia de transfecção, visto que uma série de fatores pode influenciar como, por exemplo, tamanho e quantidade de DNA, homogeneidade, $\mathrm{pH}$, temperatura, concentração de compostos da solução de transfecção e presença de DNAses [5,8,9,11]. Também um fator importante é a utilização de células que permitam uma boa eficácia de transfecção e que permitam a replicação do DNA viral transfectado, gerando partículas virais.

Assim, o objetivo do presente trabalho foi testar quatro tipos de cultivos celulares para transfecção de DNA de herpesvírus bovino tipo 5 (BoHV-5) pela técnica do fosfato de cálcio.

\section{MATERIAIS E MÉTODOS}

\section{Células e amostras virais}

As células e amostras virais foram disponibilizadas pelo Instituto de Pesquisas Veterinárias Desidério Finamor (IPVDF), Eldorado do Sul, RS, Brasil. Foram utilizadas células TT, VERO, PKsC3 e MDBK, mantidas em meio essencial mínimo de Eagle $\left(\right.$ E-MEM) ${ }^{1}$ suplementado com $10 \%$ de soro fetal bovino $^{2}$ acrescido de $2 \mu \mathrm{g} / \mathrm{mL}$ enrofloxacina ${ }^{3}$ e $4 \mu \mathrm{g} /$ $\mathrm{mL}$ anfotericina $\mathrm{B}^{4}$ a $37^{\circ} \mathrm{C}$ com $5 \%$ de $\mathrm{CO}_{2}$. O isola- do EVI88/95 foi utilizado como linhagem parental de BoHV-5 [4], sendo multiplicado em células CRIB para a obtenção de DNA viral purificado.

\section{Titulação de BoHV-5}

O título viral foi determinado pelo método Reed \& Muench [13] expresso em dose infectante para cultivo celular $/ 50 \%\left(\mathrm{TCID}_{50} / \mathrm{mL}\right)$. Para saber em que células houve maior multiplicação de BoHV-5, foram realizadas titulações em três diferentes tipos celulares: cultivo primário de células testículo de terneiro (TT), células de rim macaco verde africano (VERO) e um clone de células de rim de suíno (PKsC3). Os resultados foram comparados com a titulação de BoHV-5 em células MDBK. Para isto, foram feitas diluições seriadas na base 10 de $10^{-1}$ a $10^{-7}$, sendo adicionados $50 \mu \mathrm{l} /$ poço de cada diluição, em quadruplicata, em placas de 96 cavidades contendo as células a serem testadas. Estas placas foram mantidas a $37^{\circ} \mathrm{C}$ com $5 \%$ de $\mathrm{CO}_{2}$ e, após quatro dias, os títulos foram determinados.

\section{Transformação e extração de plasmídeos}

Os plasmídeos pRV1012+EGFP e pBSpBELO-BHV-5-Transfer foram gentilmente cedidos pelo Dr. Franciscus Antonius Maria Rijsewijk. O plasmídeo pRV1012+EGFP possui um promotor dos genes precoces do citomegalovirus humano, juntamente com o cassete de expressão para o gene da proteína fluorescente verde (EGFP). O plasmídeo pBS-pBELO-BHV-5-Transfer, além do cassete de expressão para a EGFP, possui sequências homólogas aos genes UL42 e CIRC do BoHV-5 e genes que possibilitam a multiplicação em células procarióticas do genoma de BoHV-5 recombinado a este plasmídeo.

Os procedimentos de transformação em Escherichia coli e extração dos plasmídeos foram executados de acordo com procedimentos de rotina [16].

\section{Transfecção de DNAplasmideal}

Células VERO, PKsC3 e MDKK foram transfectadas, em placas de seis cavidades, com 5 $\mu \mathrm{g}$ de DNA plasmideal juntamente com $5 \mu \mathrm{g}$ de DNA de esperma de salmão ${ }^{1}$, seguindo o protocolo descrito previamente [7]. Os resultados foram analisados em microscópio de fluorescência ${ }^{5}$, observando-se a presença de células fluorescentes no aumento de $100 X$. 


\section{Extração do DNA viral purificado de BoHV-5 EVI88/95}

A extração de DNA viral purificado foi realizada de acordo com protocolo utilizado anteriormente [4], a partir de células CRIB infectadas com BoHV-5 EVI 88/95.

\section{Transfecção de DNA viral em células TT}

A transfecção com DNA viral foi realizada segundo o método do fosfato de cálcio descrito anteriormente [5], com algumas modificações. Foram utilizadas placas de seis cavidades contendo células TT, confluência de $100 \%$. Quatro horas antes da transfecção, o meio foi trocado e as células foram transfectadas com concentrações de $0,5 \mu \mathrm{g}$ e $1 \mu \mathrm{g}$ de DNA viral.

\section{Imunoperoxidase (IPX)}

Três dias após a transfecção foi feito um teste de imunoperoxidase para detectar a presença de placas virais. Primeiramente, o meio de cultivo foi removido e as cavidades contendo as células foram lavadas três vezes com PBS Tween $80^{6}$. Após secagem, as placas foram fixadas com paraformaldeído $4 \%{ }^{7}$ gelado por 15 min e novamente lavadas. A técnica de IPX foi realizada utilizando-se anticorpos monoclonais específicos, diluídos 1:104 , de acordo com protocolo descrito anteriormente [17].

\section{RESULTADOS}

\section{Titulação de BoHV-5}

Em células VERO e $\mathrm{PKsC} 3$ a concentração viral máxima obtida foi $10^{3,3} \mathrm{TCID}_{50} / \mathrm{mL}^{-1}$, enquanto que em células MDBK o título foi de $10^{6,8} \mathrm{TCID}_{50} / \mathrm{mL}^{-1}$, similar ao encontrado para as células TT (Figura 1).

\section{Transfecção de DNA plasmideal}

A transfecção de DNA plasmideal nos diferentes tipos celulares mostrou eficácia de 4,5\% de células fluorescentes para células TT, de 2,9\% para $\mathrm{PKsC} 3$, de 0,5\% para VERO e de 0,05\% para MDBK (Figura 2).

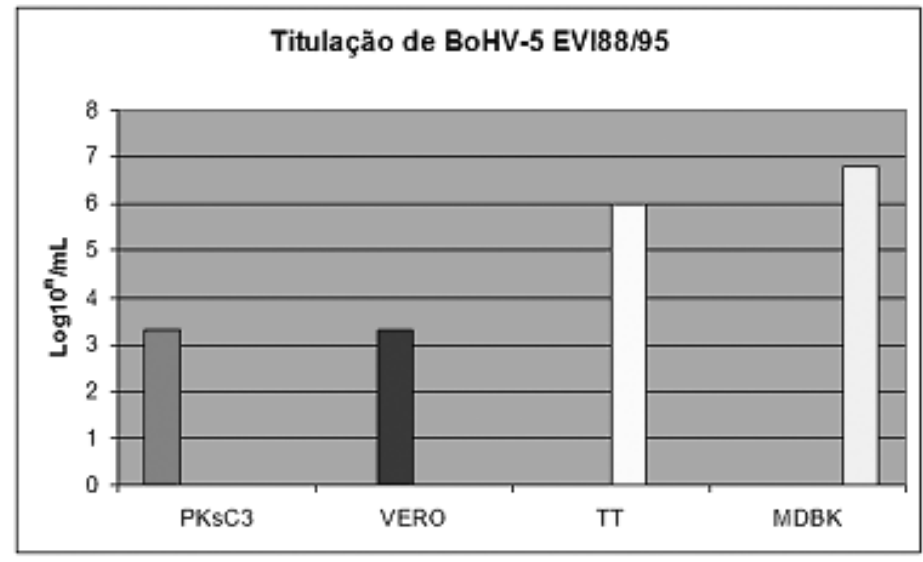

Figura 1. Titulação do BoHV-5 EVI88/95 cultivado em células PKsC3, VERO, TT e MDBK. Resultados representam a média de quadruplicatas, em $\mathrm{TCID}_{50} / \mathrm{mL}$. Em células VERO e PKsC3 a concentração viral máxima obtida foi $10^{3,3} \mathrm{TCID}_{50} / \mathrm{mL}^{-1}$, enquanto que em células MDBK o título foi de $10^{6,8} \mathrm{TCID}_{50} / \mathrm{mL}^{-1}$, similar ao encontrado para as células TT.

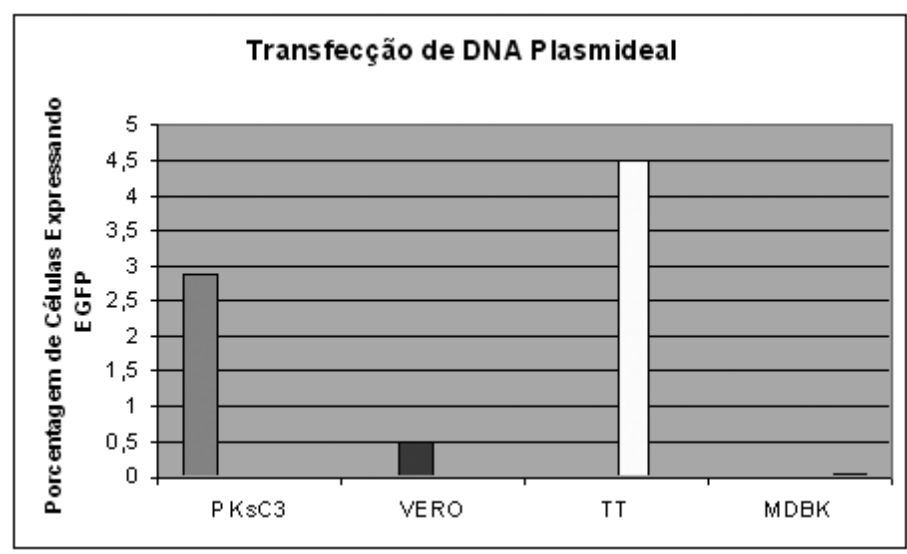

Figura 2. Transfecção de DNA plasmideal nos diferentes tipos celulares. O número médio de células expressando EGFP foi determinado pela contagem das células em 5 diferentes campos microscópicos (aumento de 100X). A eficácia foi maior para células TT (4,5\%) e células PKsC3 (2,9\%). 


\section{Transfecção de DNA viral em células TT}

A avaliação da eficácia de transfecção pelo teste da imunoperoxidase mostrou que com $500 \mathrm{ng}$ de DNA viral foi possível obter duas placas virais, dobrando este número quando se utilizou a concentração de 1000 ng.

\section{DISCUSSÃO}

O método de transfecção por fosfato de cálcio descrito originalmente [5] possui variáveis que podem ser ajustadas para que se melhore a eficácia, entre as quais o tipo de célula utilizado. Para isso, é necessário que a célula possua grande capacidade de endocitar o precipitado de fosfato de cálcio com DNA $[1,3,20]$ e que também possibilite a multiplicação do DNA viral transfectado, gerando partículas virais infecciosas $[15,19]$. Neste trabalho foram testados o tipo celular mais apropriado e o grau de eficácia da multiplicação de BoHV-5 nos diferentes tipos de células. Os resultados das transfecções com $5 \mathrm{mg}$ de DNA plasmideal demonstraram que dentro do grupo de células transfectadas, o melhor resultado foi obtido com células TT, que apresentaram um percentual de 4,5\% de células fluorescentes. Segundo alguns autores [18], apenas 7\% do DNA viral transfectado alcança o citoplasma e apenas $0,5 \%$ chega intacto ao núcleo celular, sendo necessária uma grande quantidade de DNA para se obter maior eficácia de transfecção.

A concentração viral máxima de BoHV-5 em células TT foi de $10^{6} \mathrm{TCID}_{50} / \mathrm{mL}$, comparável ao título obtido em células MDBK, que foi de $10^{6,8} \mathrm{TCID}_{50} / \mathrm{mL}$. Embora com as células MDBK tenha havido uma boa multiplicação viral, a eficácia de transfecção foi a menor entre os tipos celulares testados $(0,05 \%)$, indicando uma baixa capacidade de endocitose do precipitado de fosfato de cálcio. Prasad et al. [12] testaram doze diferentes tipos de células para analisar a influência da endocitose na eficácia de transfecção de DNA plasmideal pCMV $\beta$-gal com CLDC (Cationic Liposome DNA Complex). Os autores observaram uma correlação positiva entre o número de células transfectadas e a capacidade de endocitose de cada tipo de célula, sendo detectada uma diferença de até 15 vezes no número de células transfectadas entre os tipos celulares. Em nosso estudo a transfecção de DNA viral purificado em células TT foi baixa, mesmo quando transfectadas com $1000 \mathrm{ng}$ (quatro placas virais). Por estimativa, teríamos uma média de 20 placas virais por poço em placas de seis cavidades com a transfecção de 5000 ng de DNA viral purificado. Mesmo assim, este número de placas virais ainda seria insuficiente para a obtenção de um vírus recombinante, já que a chance de recombinação é um evento ocasional com frequência muito baixa [21].

\section{CONCLUSÕES}

Nas condições experimentais testadas neste estudo os resultados indicam que as células TT poderiam ser boas candidatas para serem utilizadas para a transfecção de DNA de BoHV-5. Entretanto, mais experimentos serão necessários para se testar as melhores condições para se obter uma melhor eficácia de transfecção, suficiente para a obtenção de vírus recombinantes.

\section{NOTAS INFORMATIVAS}

${ }^{1}$ Gibco-Invitrogen, São Paulo, Brasil

${ }^{2}$ Cultilab, Campinas, Brasil

${ }^{3}$ Baytril/Bayer, Porto Alegre, Brasil

${ }^{4}$ Cristália, São Paulo, Brasil

${ }^{5}$ Nikon Eclipse E400, Kanagawa, Japão

${ }^{6}$ Vetec, Rio de Janeiro, Brasil

${ }^{7}$ Merck, Darmstadt, Alemanha

\section{REFERÊNCIAS}

1 Cartier R., Velinova M.l., Erdmann B. \& Reszka R. 2003. Ultrastructural Analysis of DNA Complexes During Transfection and Intracellular Transport. The Journal of Histochemistry \& Cytochemistry. 51 (9): 1237-1240.

2 Ciftci K. \& Levy R.J. 2001. Enhanced plasmid DNA transfection with lysosomotropic agents in cultured fibroblasts. International Journal of Pharmaceutics. 218 (1-2):81-92.

3 Coonrod A., Li F.Q. \& Horwitz M. 1997. On the mechanism of DNA transfection: efficient gene transfer without viruses. Gene Therapy. 4(12): 1313-1321.

4 Franco A.C., Hubner S.O., Oliveira A.P., Batista H.B.C.R., Roehe P.M. \& Rijisewijk F.A.M. 2007. Construction and characterization of a bovine herpesvirus 5 mutant with a deletion of the gI, gE and US9 genes. Brazilian Journal of Microbiology. 38(4): 667-673. 
5 Graham F.L. \& Van der Eb A.J. 1973. A new technique for the assay of infectivity of human adenovirus 5 DNA. Virology. 52(2): 456-467.

6 Indrajit R., Susmita M., Amarnath M. \& Subho M. 2003. Calcium phosphate nanoparticles as novel non-viral vectors for targeted gene delivery. International Journal of Pharmaceutics. 250(1): 25-33.

7 Kuroda S., Kondo H., Ohya K. \& Kasugai S. 2005. A new technique with calcium phosphate precipitate enhances efficiency of in vivo plasmid DNA gene transfer. Journal of Pharmacological Sciences. 97(2): 227-233.

8 Lechardeur D., Sohn K.J., Haardt M., Joshi P.B., Monck M., Graham R.W., Beatty B., Squire J., O’Brodovich H. \& Lukacs G.L. 1999. Metabolic instability of plasmid DNA in the cytosol: a potential barrier to gene transfer. Gene Therapy. 6(4): 482-497.

9 Oltona D., Li J., Wilsona M.E., Rogersa T., Closed J., Huange L., Kumtaa P.N. \& Sfeir C. 2007. Nanostructured calcium phosphates (NanoCaPs) for non-viral gene delivery: Influence of the synthesis parameters on transfection efficiency. Biomaterials. 28(6): 1267-1279.

10 Pascal B., Martin J. \& Florian W. 2001. Transfer of high copy number plasmid into mammalian cells by calcium phosphate transfection. Gene. 270(1-2): 61-68.

11 Pedraza C.E., Bassett D.C., McKee M.D., Nelea V., Gbureck U. \& Barralet J.E. 2008. The importance of particle size and DNA condensation salt for calcium phosphate nanoparticle transfection. Biomaterials. 29(23): 3384-3392.

12 Prasad T.K., Rangaraj N. \& Rao N.M. 2005. Quantitative aspects of endocytic activity in lipid-mediated transfections. FEBS Letters. 579(12): 2635-2642.

13 Reed R.H. \& Muench H. 1938. A single method of estimating fifty percent end points. American Journal of Hygiene. 27: 493-497.

14 Rissi D.R., Rech R.R., Flores E.F., Kommers G.D. \& Barros C.S.L. 2007. Meningoencefalite por herpesvírus bovino - 5. Pesquisa Veterinária Brasileira. 27(7): 251-260.

15 Sheldrick P., Laithier M., Lando D. \& Ryhiner M.L. 1973. Infectious DNA from Herpes Simplex Virus: Infectivity of Double-stranded and Single-stranded Molecules. Proceedings of the National Academy of Sciences. 70(12): 3621-3625.

16 Sambrook J., Fritsch E. \& Maniatis T. 1989. Molecular cloning: A Laboratory Manual. 2nd. edn. New York: Cold Spring Harbor Laboratory, pp.1.21 and 1.74.

17 Souza V. F., Melo S.V., Esteves P.A., Schmidt C.S., Gonçalves D.A., Schaefer R., Silva T.C., Almeida R.S., Vicentini F., Franco A.C., Oliveira E.A., Spilki F.R., Weiblen R., Flores E.F., Lemos R.A., Alfieri A.A., Pituco E.M. \& Roehe P.M. 2002. Caracterizaçäo de herpesvírus bovinos tipos 1 (BHV-1) e 5 (BHV-5) com anticorpos monoclonais. Pesquisa Veterinária Brasileira. 22(1):13-18.

18 Strain A.J. \& Wyllie A.H. 1984. The uptake and stability of simian-virus-40 DNA after calcium phosphate transfection of CV-1 cells. Biochemical Journal. 218(2): 475-482.

19 Van Zijl M., Quint W., Briaire, J., Rover T., Gielkens A. \& Bems A. 1988. Regeneration of herpesviruses from molecularly cloned subgenomic fragments. Journal of Virology. 62(6): 2191-2195.

20 Welzel T., Radtke I., Meyer Z.W., Heumann R. \& Epple M. 2004. Transfection of cells with custom-made calcium phosphate nanoparticles coated with DNA. Journal of Materials Chemistry. 14(14): 2213-2217.

21 Zhijian W., Xiaobing W. \& Yunde H. 1999. Generation of a recombinant herpes simplex virus which can provide packaging function for recombinant adeno-associated virus. Chinese Science Bulletin. 44(8): 715-719. 